\title{
The United States' Interest in the Guaraní Aquifer in Paraguay
}

\author{
Eduardo Tamayo Belda \\ Universidad Autónoma de Madrid
}

The control and extraction of natural resources throughout the world -like water-is part of the global strategy of the United States of America in order to maintain a hegemonic position in the commodities market in energy, agriculture or mining exploitation sectors. This text studies the United States interests and those of global companies supported by them in relation to the water resource located in Paraguayan territory called Guarani Aquifer (being of high geostrategic importance); it also analyzes the current national Paraguayan regulation that can guarantee the public ownership and management of water, avoiding the penetration and preponderance of private or foreign interests.

Keywords: Guarani Aquifer, extractivism, water, Paraguay, United States of America

\section{INTRODUCTION}

The control and extraction of natural resources throughout the world is part of the global strategy of the United States in order to maintain a hegemonic position in the commodities market in energy, agriculture or mining exploitation sectors, thus contributing to the maintenance of its privileged status in world geopolitics, despite the emergence of China and the importance of other groups of international actors. So far, in spite of being a concerning source of international conflict mainly in those areas where it is really scarce, the issue about water disputes is not receiving enough importance considering its strategic value in the medium and long term. It seems obvious that water - a strategic resource in world geopolitics - will shortly become a source of serious international confrontation and, in this sense, the United States is already taking positions for that future global competition.

The system known as the Guaraní Aquifer is a vast underground reserve with an approximate area of $1,200,000 \mathrm{~km}^{2}$, spread over the countries of Brazil (where most of the aquifer accumulates), Argentina, Uruguay and Paraguay. In the last decades there has been a slow and silent attempt to control and take strategic positions in the region under which one of the world's largest underground water reserves is located, and in most cases agents of the United States or actors related to their interests were involved. This text specifically studies the interests of the United States and those of global companies supported by the United States in relation to this water resource located in Paraguayan territory and being of the highest geostrategic importance; it also analyzes the current national Paraguayan regulation that can guarantee the public ownership and management of water, avoiding the penetration and preponderance of United States interests that, in the medium and long term, would undoubtedly generate strong tensions in Paraguay. These could acquire an "anti-american" or "anti-imperialist" character, and could become, thus, a series of local, national or regional resistances against the interests of the United States and those of the large extractivist corporations linked to the Guarani Aquifer. 


\section{THE GEOPOLITICS OF WATER AND WATER RESOURCES IN SOUTH AMERICA}

Despite the great abundance of water that exists on Earth, $99.7 \%$ of its reserves are not suitable for human and animal consumption, and of the existing fresh water, seven million cubic miles are frozen at the poles and glaciers, about three million in the atmosphere, and two million more in groundwater (mostly) lakes and rivers (Ceceña \& Motto, 2005, p. 10).

To date, the dispute over water does not represent a very worrying source of international conflict (except in areas where it is really scarce); however, the strategic positioning of multinational companies in the places that constitute the world's great water reserves is evident, as well as that of the great powers (mainly the United States). The United States has its sights set, in particular, on the exploitation of these reserves, for which it tries to control both the ownership of the land under which the water is located and the public regulation of its exploitation, as part of its global economic strategy. In this context of interests - undoubtedly conflicting - the problem of water scarcity at a global level is directly and intimately related, among other factors, to the unequal distribution of water resources in relation to the geographic concentration of the population and, "in this sense, it should be noted that Latin America is a privileged subcontinent in terms of water availability" (Ribeiro, Bermúdez \& Leal, 2015, p. 100). In fact, South America represents the best of the possible scenarios at a global level for the extraction of water resources, since it has the most favorable relation between water availability and population on the planet, containing around $26 \%$ of the world's water reserves and representing only $8 \%$ of the population (PNUD Paraguay, 2006 , p. 15). In the Asian case, that ratio is $36 \%$ of water availability, compared to $60 \%$ of the population.

Specialists on the issue such as Reydulf K. Molvaer or Indra De Soysa have pointed out that the reasons for wars have often been disputes to gain or maintain access to natural resources, and that threatening situations constantly arise or develop on the international scene related to the control of these resources (Apuuli, 2011, p. 68); thus, the abundance of natural wealth in the form of potentially exploitable resources is closely related to the emergence of conflicts of different kinds, mainly in those regions where these reserves are shared. This is the case since the management of natural resources (even the cross-border resources) is tightly linked to the national sovereignty of competing States and societies, involving a wide variety of laws, interests and organizations. In this game of interests, the privatizing pressures of the current neoliberal model generate the need for a participatory governance scheme involving local, regional and national levels, and one which addresses conflicts within a global framework that guarantees the observance of human rights while developing a new status of global citizenship (Arrojo, 2009, p. 53). According to Díaz Alpuente: "coming from other stronger and more established areas, the norms of the international water regime do not fit into a common corpus, thus fostering conflicts instead of reducing them" (Díaz Alpuente, 2009, p. 217).

The need to promote a sustainable development of the economy at a global level, one which also favors the well-being of the world population, has led the social sciences to focus on the analysis and research in the legal and social nature of resources, and the conflicts resulting from the struggle for their control and exploitation. In this regard, it is assumed that, within the spectrum of International Relations theories, this work starts from a realistic conception of the management of natural resources - in this case water-; that is to say, the paradigm that emphasizes the role of the State as an actor that "plays an important role through its main function of defining property rights and responsibilities" of the organizations or institutions with competencies for managing the water resources of a country. Thus, in modern pluralist democratic societies, the foundations of the State rest on the publicization - here, the word "publicization" is used as a synonym of "nationalization", or "turn into public management"- of the management of the costly control and surveillance necessary to protect the assets and the product so these are not distributed according to unknown or intrusive interests (Rogers, 2002, p. 6).

Nevertheless, this text also takes into account other perspectives aimed at completing such a vision of water with an approach to the phenomenon of water exploitation and its casuistry from positions different from the realistic one. This includes, for instance, those works that emphasize the complexity of the dualism between society and nature, based on the conception of water as a "social resource," understanding that it is something more than a simple "natural resource," and expanding "the idea of water as a vital element for 
ecosystems." This would be necessary for "the reproduction of life both in urban and rural areas" (Larsimont \& Grosso, 2014, p. 29), and these other theoretical views provide, in the discussion about the idea of "Nature" and the way of thinking about it, arguments that allow for "conceptualizing and politicizing it, in an effort to confront the disastrous socio-ecological condition of the planet" (Larsimont \& Grosso, 2014, p. 30). The work of Linton and Budds (2014, pp. 170-180) runs along the same lines, addressing the concept of "hydro-social relations" and theorizing about the relationship between water and human life in society (Linton \& Budds, 2014, p. 173).

In the United Nations Sustainable Development Goals 2030 (hereinafter SDG-2030), special emphasis is placed on the need to safeguard water as a vital resource and a universal human right; the permanent guarantee of access to water constitutes a fundamental basis in sustainable human development and, in fact, is an element on which the rest of the objectives depend: well-being, poverty reduction, quality environment, etc. In the world, $70 \%$ of drinking water is used for agricultural production, as Jägerskog indicates in his 2013 report for UNESCO (Jägerskog, 2013). In this context, the will to facilitate and promote economic development converges with the need to generate and safeguard inclusive policies to equitably manage a resource as valuable as water, which is also a human right. On 28 July 2010, through Resolution 64/292, the United Nations General Assembly explicitly recognized the human right to water and sanitation and acknowledged that clean drinking water and sanitation are essential to the realisation of all human rights. The Resolution calls upon States and international organisations to provide financial resources, help capacity-building and technology transfer to help countries, in particular developing countries, to provide safe, clean, accessible and affordable drinking water and sanitation for all.

The situation in Latin America with respect to environmental sustainability represents a challenge: the region constitutes the area with the highest demographic growth, with a population of 596 million inhabitants, which explains the growing pressure on natural resources - especially on water-, and the intensification of the demand for land and the growth of urbanization. Throughout the region, the water problem is largely conditioned by conflicts derived from the unequal distribution of water resources in relation to population concentration. Only in South America, $26 \%$ of the world's water availability is concentrated, with Brazil, Colombia, Argentina and Paraguay being the countries with the highest proportion of this resource. However, while Latin America is the region of the planet with the highest demographic growth and pressure on resources, the paradox arises that it is also the region that shows the most comfortable relation between water availability and number of inhabitants, even when there are serious difficulties in accessing drinking water in some areas.

Of course, there are also national and international conflicts of interest due to its exploitation; in 1995, Ismail Seragueldin - then Vice President of the World Bank - asserted that "water will be the main cause of conflict in the 21 st century, just as oil was in the 20th century," a statement that highlights a new type of conflict known as "water wars." Alarmist arguments notwithstanding, it is not possible to continue ignoring these circumstances; it is necessary to become aware of the situation and assume that it is a reality which already permeates our societies, with greater intensity in some regions of the world than in others.

Unlike oil or other extractive resources, water has a unique characteristic: it is a "non-static" resource. That is, its use or exploitation at a point of its location or its course has clear and early consequences somewhere else; there are 276 river basins in the world that cross the borders of at least two countries, something that shows the importance of international regulation of access to water.

If we consider that South America has the largest reserves of fresh water, we must bear in mind that this is not just a proclamation of the geographical virtues and tourist attraction of the region; it is an outstanding geographical fact. The Amazon system — with more than 8 million $\mathrm{km}^{3}$ —, the Río de la Plata basin system — with 3 million $\mathrm{km}^{3}$ — and the Guaraní Aquifer system — which has almost 2 million $\mathrm{km}^{3}$ constitute the main water accumulations of the continent. These systems and basins include rivers, wetlands, lakes, lagoons and groundwater, but, within the context of these reserves, some countries cover more water than others: Brazil is part of these three basin systems, while Argentina and Paraguay are part of two of these cross-border water systems. As a result, Paraguay has - despite its small size and low population density- more than 4 million $\mathrm{km}^{3}$ in water resources, only surpassed by the Amazon system. 
The numbers at stake are enormous; for this reason, public operation and political management of these resources becomes a fundamental issue, since they constitute both vital resources for the population and important sources of public and / or private enrichment. It must be borne in mind that according to the UNDP the region made up of "Latin America and the Caribbean has intense conflict, in which socioenvironmental conflicts represent $63 \%$ of all social conflicts" (Echart \& Villarreal, 2018, p. 152), while the international bridges to settle them seem not to be in place: in 2011, a report warned about the scarce or non-existent multilevel cooperation in the region in matters of administration and legislation on crossborder water resources (Ackmouch, 2012), showing that the region did not have at the beginning of the 21st century an organic structure that mediated between countries and their interests, while protecting water resources in a cooperative scheme. This context of fragmentation - and the consequent legal uncertainty at the national level - represents the ideal breeding ground for capital interests, with the capacity to organize multinational platforms of an extractivist nature, appealing to concepts such as "progress" or "development," and forcing Governments to carry out policies in the interest of the international markets.

Other authors also point to this same line, noting that "the fallibility of the concept of the nation-state as a guarantor of sovereignty over natural assets is evidenced," (...) since they "are part of an interconnected ecosystem where the modification of one part has consequences for the rest" (Ortega \& Portillo, 2015, p. 106). Given these circumstances, existing national or international laws "seek to artificially distribute among the States" jurisdiction over resources, which "complicates the definition of responsibilities and risks in their use and protection," and this is how "it opens a loophole used by international organizations at the service of transnational companies, to carry out studies and elaborate treaties and recommendations on the supposedly most appropriate and rational way of managing these assets as natural resources for their better use, that is, their better exploitation" (Ortega \& Portillo, 2015, p. 107).

If we discard the poles as an extractive zone, the world's largest reserve of fresh water would be concentrated in the glaciers of southern Argentina and Chile, but the current state of technology and profitability requirements still make the massive exploitation of this glacier water a complex process, and this keeps the strategic business interest away from these areas (Ceceña \& Motto, 2005, pp. 10-11); such situation reinforces the importance of other more accessible reserves such as onshore deposits - surface or underground-, which proclaims a clear importance of South America in this matter, since there are not many sources or large-volume accessible deposits worldwide. The Guaraní Aquifer and the Amazon River basin stand out here - in addition to the Congo River - due to their geostrategic importance (Ceceña \& Motto, 2005, p. 11).

Unfortunately, the result of poor regulation in South American countries, along with the inaction and lack of initiative or budgetary support from these governments to achieve strict control (especially in rural areas or those ones distant from areas of greater population concentration), together with the impossibility of sub-national agents to orchestrate effective measures on the water resources of which they try to become sentinels, ends up converging in the kind of unfortunate situation widely known in the region: political disinterest and the presence of the usual and deep-rooted corrupt practices within local, regional and state bureaucracies. As Martín and Justo point out, this "problem of lack of effective operation is an important limitation to the effectiveness of management systems: while, on the one hand, it is given broad theoretical powers of management, planning and policy, on the other, the powers of control and effective implementation, and their instrumentation, are extremely weak;" according to their research this is a common problem in most Latin American countries (Martín \& Justo, 2015, p. 28).

In light of the challenge of meeting the goals proposed in the SDG-2030, voices arise which, from the growing skepticism, question whether the current drift towards deregulation, liberalization and decentralization - typical of the perspectives of the global governance paradigm, such as those proposed by Food and Agriculture Organization (FAO, 2016) - , will be appropriate and sufficient to protect water resources from private interests. Moreover, it is also questioned whether water will be taken into account as a fundamental resource for life - and therefore constitutive of law-, in order to guarantee the conceptualization of water resources, in line with the approaches of Barlow and Clarke (2004), as a public good and a human right. 
Finally, it is important to highlight the role that land plays in South America - particularly clear is the case of Paraguay-, where it constitutes a fundamental productive factor; thus, the region is not only characterized by the availability of water, but also by the abundance of land at a relatively low cost, an issue that has been decisive for the installation of extractive companies - mostly foreign enterprises - over time. This combination of profitability in access to land and water is what makes South America more attractive compared to other regions of the world and, therefore, susceptible to conflict over resources, an issue in which Paraguay turns out to be one of the paradigmatic cases of this geopolitical phenomenon.

Thus, when thirty years have passed since the beginning of democracy in the Paraguayan Republic, it is imperative to assume and decisively confront the importance that water is going to have for the country in the decades to come. Next, the text focuses on Paraguay, and analyzes the current situation of legal protection of the Guaraní Aquifer in the country. This aquifer is a vast transnational groundwater reserve whose main point of access and natural recharge is precisely on Paraguayan soil, but which also occupies the territory of Brazil, Argentina and Uruguay. International attempts to control access, management and exploitation of this resource - mainly those of the United States and multinational companies whose interests are shared - are also addressed.

\section{THE WATER SCENARIO IN PARAGUAY AND ITS LEGAL FRAMEWORK}

Paraguay is a country privileged by the great abundance of water in a large part of its territory and by the quality of these water resources, located both on the surface - in the basins of the Paraná and Paraguay rivers - and in the subsoil, waters that for the most part belong to the so-called Guaraní Aquifer, which with an approximate extension of $1,200,000 \mathrm{~km}^{2}$ is one of the world's largest reserves of fresh underground water. The potential of Paraguay's water wealth is enormous - the dams that supply $100 \%$ of the electricity consumed by the country, still leaving energy surplus for export, give a solid proof of it - and the magnitude of the possible undertakings and uses of this water wealth is something that the Paraguayan State must consider with calm and dedication, based on solid studies and not on circumstantial political expediency or on the haste to get funds immediately if that sacrifices an important part of such potential.

Although this text only addresses the casuistry of the Guaraní Aquifer, there are many water spaces in Paraguay associated with cross-border management: upper basin of the Paraguay river, Pantanal sector (with Brazil), Apa river basin (with Brazil), basin of the Paraná river (with Brazil and Argentina), lower basin of the Paraguay river (with Argentina), Pilcomayo river basin (with Argentina and Bolivia), and the Toba Tarijeño aquifer (with Argentina and Bolivia). In addition, there are inland aquifers in the country such as the smaller Patiño aquifer - that supply the local population.

However, despite the fact that only $6 \%$ of the surface of the Guaraní Aquifer is in Paraguayan territory - practically all of the so-called eastern Paraguay — the reality is that the importance that this Paraguayan sector has for the aquifer system as a whole is much greater than the suggested by that figure. The reason is, firstly, that a large volume of groundwater is concentrated in that $6 \%$ of surface located on Paraguayan territory and, secondly, that the area also constitutes one of the main aquifer recharge areas, so in order to guarantee the sustainability of the Guarani Aquifer in its entirety, it is necessary to ensure the quality of its ecosystems in the territory of Paraguay, thereby protecting the hydrological cycle of the system; otherwise, a large part of the aquifer's potential — even in other countries - will be lost.

This is why, in the medium term, the legal protection related to aquifers should not only pay attention to the water itself, but also to the sustainability of the system, protecting the recharge areas and the complete hydrological cycle; this matter is, in general, ignored by foreign companies and governments due to lack of interest, as they are attracted by the benefit of the direct extraction of water in Paraguay for its commercialization.

With regard to the possibilities of water extraction, there are two facts that put the focus on what happens in Paraguay: in its territory the aquifer practically emerges, and the use of agrochemicals in the agriculture is very high in the country, and according to data from Apipé (2018, pp. 32-35), 6.2\% of the agrochemicals that were sold in 2017 in the world were imported by Paraguay (with deregulation and total lack of control of the purchase and use of these products in the country). As a result of this the waters of 
the aquifer in this region run a serious risk of being contaminated, thus losing this resource a large part of its potential, since groundwater has the comparative advantage over surface waters that it does not need excessive treatment for its purification, as it is generally filtered and protected from external toxic agents discharged by human beings on the surface. In fact, a groundwater system such as the Guaraní Aquifer took thousands of years to fill, so its excessive contamination could be an irreparable damage in the medium or long term by not being possible the purification of the waters naturally at the necessary speed for use on a human scale.

In 2000, Fernando Costantini (pp. 105-106) considered that it was "curious" that the Paraguayan National Constitution of 1992 did not refer in its articles to agrarian issues related to the water factor, nor did it take into account this resource as an essential element for take-off and growth of Paraguayan agrarian wealth; in his opinion, the availability of water and the inexistence of a supposed "water problem" in the country were taken for granted, despite the fact that there are areas in the Chaco region that are affected by these issues, and that the potential of this resource is so vast in Paraguay that deregulation due to inaction of the competent authorities leaves too much room open to other economic groups, which could take advantage of this public lack of interest in the effective control of water resources.

Nevertheless, although no specific regulations on water resources have been included in it, the Paraguayan Magna Carta incorporates - consistently with the time of its enactment — the right to a healthy environment (in Article 7), explicit provisions for environmental protection (Article 8) and the supranational nature of human rights (Article 145), also guaranteeing all inhabitants equal opportunities in sharing the benefits of nature (Article 47), "among other stipulations that provide a relatively modern general legal constitutional framework to the particular statutes relative to the waters" (Embid \& Martín, 2015, p. 24).

Since then, Paraguay has progressed in legislation for the protection of its water resources - and in particular its groundwater - although it has done so too slowly for a country that depends economically on its natural resources much more than others, as neither the industrial sector nor the tertiary sector are yet strongly developed. A milestone in this regard was the enactment of Law No. 1561 of the year 2000, by which the Secretariat of the Environment (SEAM, Secretaria del Ambiente) was created and the first legislative regulations on national waters were generated, as part of the National System of the Environment (Sistema Nacional del Ambiente). Years later, Law No. 3239 of 2007, "On the water resources of Paraguay" ("De los recursos hidricos del Paraguay"), compiled most of the fundamental aspects for the defense of water as a human right and its protection as a good exclusively of public control, which have been discussed in the first part of this work; this law expanded some of the aspects that had already been legislated by the Secretariat of the Environment in its resolutions No. 2155 of 2005 and No. 50 of 2006. Recently, Law No. 6123 of 2018 elevated SEAM to the rank of National Ministry, being renamed Ministry of the Environment and Sustainable Development (MADES, Ministerio del Ambiente y Desarrrollo Sostenible), an organization that was effectively constituted by that same law "in the Authority for the Application of Law No. 3239/2007."

Until 2018, Paraguayan normative texts included most of the legal requirements that can be demanded from a State to guarantee the protection and public ownership of the country's water resources. Until that year, the main problem lied in the excessive fragmentation in the regulation and in the competent entities, which made the administration and management of problems and conflicts over water ineffective. During the first years of the transition, in addition to this institutional fragmentation, there was a scarce and vague regulation in this regard, which from 2005 onwards has been improved rather slowly, also intensifying the generation of sanctioning regulations in the administrative field, which however were rarely fulfilled due to such fragmentation in the competent legal system. The fact that a specific authority was not defined, together with the aforementioned delay in its regulation, raises doubts that the level of application and effectiveness of the Law and the legislative resolutions have been appropriate all this time.

However, as of 2018, the Ministry of the Environment and Sustainable Development has been clearly assigned the powers of control and sanction, and this body is exclusively responsible for ensuring that the country complies with what is dictated by Law No. 3239, which in its Article 3 states that "the waters, surface and underground, are property of the public domain of the State and their domain is inalienable and 
imprescriptible," to which it adds in another section of the same article that "the Paraguayan State holds the non-transferable and non-delegable function of the ownership and custody of national water resources," leaving little room for creative interpretation in this regard.

In addition, that same Article 3 refers to the nature of water as a public right, stating that "access to water for the satisfaction of basic needs is a human right and must be guaranteed by the State, in adequate quantity and quality," also pointing out that "water resources have a social, environmental and economic value."

It is essential to address one last characteristic of the legal protection of water resources in Paraguay: the necessary protection of the water currently accumulated in the aquifers is not enough, but it is also required to guarantee that it is managed, in manner and rhythm, according to criteria that allow the adequate renewal of these resources and that prevent their contamination or their drastic reduction. For this, Law No. 3239 rightly points out in that same Article 3 that "water resources are a finite and vulnerable good," and also establishes that "the management of water resources must take place within the framework of sustainable development, it must be decentralized, participatory and with a gender perspective"; this is reasserted in Article 4, which determines as objective of the National Water Resources Policy (Politica Nacional de Recursos Hidricos) "to promote the sustainable, rational and integral use of water resources, as a conditioning element of the survival of the human race and of the entire ecological system."

In view of the foregoing, it seems clear that, to date, Paraguay has the legal regulation in place that would guarantee that three fundamental aspects are met: a) water in the national territory is a public good and is property of the State; $b$ ) access to water is a human right that the State must guarantee to all citizens; and c) the State undertakes the necessary protection of water resources and their sustainable management.

However, in order to complement the previous appreciation, it would be necessary to carry out an indepth analysis about the effectiveness of the application of this legal framework, and also about its own limitations, since, certainly, there are doubts about the fulfillment and real scope of those regulations put on paper; the point is that if we look at the recent history of Paraguay, a justified uncertainty should assail us about the possibilities of the Paraguayan State as an institution to prevent the misappropriation and inadequate management of the country's water resources, since there is a long history of permissive legislation and political softening towards external interests - especially, but not only, those of the United States and some large corporations - as well as of facilitating re-offending in a corruption sadly normalized in many areas of public administration, which would generate the perfect breeding ground to dodge national legislation in this case too.

Placing the focus on the regulation implemented by Paraguay is also peremptory if we consider the mediating role that the country might have to play by "acting as a 'cushion' between two potentially hostile units" - Argentina and Brazil—, as Maximiliano Barreto points out (2016, p. 9); this author explores in a recent text the "geopolitical uses of Paraguay," recovering the realistic dialectic of the concept of "buffer state," and assigning the country a cooperative role at the regional level, because the construction of a normative framework in the terms proposed by Ken Conca (2006) - as a kind of supranational government for the management of resources at a global level - is still in an incipient stage in the given casuistry.

In Fretez's opinion (2017, p. 73), the mega-regional agreements currently in force in Latin America TPP, TTIP, RCEP, and TISA - reconfigure the productive structures of the signatory countries with the aim of modifying state regulatory norms in favor of the private interests of large international corporations, becoming what this author considers "true straitjackets for the States, nullifying their ability to regulate and intervene in their national economies" (Fretez, 2017, p. 74).

\section{INTERNATIONAL INTERESTS IN THE GUARANÍ AQUIFER}

Once the situation of Paraguay has been valued with respect to its water potential, and its regulation has also been reviewed, the current presence of strong international interests regarding the ownership and possible exploitation of the existing water resources in the Paraguayan subsoil is analyzed, specifically the attraction due to the enormous amount of water accumulated in the Guaraní Aquifer, which arouses the 
interest of both multinational companies and the governments of foreign powers such as the United States of America.

In 2005, the Argentine documentary "THIRST: invasion drop by drop" ( "SED: invasión gota a gota" directed by Mausi Martínez in 2004, indicated in the bibliography) was released, in which the interviewed specialists warned about two access strategies by foreign actors - mainly companies or the US government itself - to South American water resources. The first of these strategies consists of the installation of military bases in key points of the region that allow the control of these resources (based on the new concept of global antiterrorist fight); the second of the strategies aims at the privatization of water and the water purification service - processes sponsored by institutions such as the World Bank and other international financing organizations-, allowing multinationals and developed countries to gain ownership or control of such resources.

Since then - and more intensely in recent years - there has been frequent news related to the alleged North American interests in the exploitation of Paraguayan water resources, specifically the Guaraní Aquifer.

A news item from 2015 echoed the purchase by the Bush family of 121,407 hectares in Paraguayan territory that, according to the news (Jalife-Rahme, 2015), would settle — at least in part — on the Guaraní Aquifer; in the years of the purchase (2005 and 2006), the Paraguayan Government - headed by Nicanor Duarte Frutos - was being advised in various areas of public management by the World Bank (among other international organizations). However, it is not only a matter of the interest of the Bush family in doing private business, but the US State seeks to position itself in the area, knowing the enormous economic potential of the resource. That is why the United States marks the place as one of the conflictive points and of national interest; for the implementation of its policies, the United States "needs security, and for them the only possible security is that which results from the presence of its militarization scheme," points out Marielle Palau (2006, p. 343); a "security" that in the author's opinion "does not limits to the physical presence of the troops, but includes an intelligence system and a specific operational capacity." In the scheme of militarization of the United States in the Latin American Southern Cone region, a fundamental importance is assigned to Paraguay, which at the beginning of the 21 st century "emerged as a point of radiation or nerve center" (Ceceña \& Motto, 2005, p. 19) of the North American military deployment in this area; Paraguay approved in 2005 a new antiterrorist law that, although "it does not really represent a great change for the country" (Ceceña \& Motto, 2005, p. 20), is related to general changes in the security regulations in the region, behind which are precisely the United States with "the Pentagon's project to create a Network Centric Warfare at a global level that would function as a large centralizing node for information from around the world" (Ceceña \& Motto, 2005, p. 21), and Paraguay "is at one end of the 'critical area' of the world ("the gap") delineated on the Pentagon Map" (Ceceña \& Motto, 2005, p. 23).

For the same reason, the discourse of global securitization in the Triple Frontier (Brazil-ArgentinaParaguay) has intensified more recently; putting the focus of attention on an alleged threat of actions by organizations related to global terrorism in the region allows placing institutions, infrastructures, investigative teams and military forces on the ground, in the fundamental strategic place to control one of the most important areas of the aquifer (the point of contact between three of the countries involved and which also constitutes one of the key areas of access to the system). This would explain the escalation in the growing media coverage of international crime - and in particular the possible terrorist activity — both in the Triple Frontier (where the North American security agencies repeatedly warn about the presence or financing of jihadist terrorism), and in the interior of Paraguay, insisting - also with North American knowledge and collaboration - in the danger posed by the Paraguayan People's Army -EPP, Ejército del Pueblo Paraguayo - thus justifying the presence of Paraguayan military forces deployed in agricultural rural territory (Resumen Latinoamericano, 2015), which also guarantee the interests of the United States and those of the great national agribusiness entrepeneurs, getting to have the police and the armed forces "to do their dirty work in the matter of repression of social and popular movements" (CEPRID, 2013). With the beginning of the so-called "global war on terror" initiated by the Bush Administration after the 9/11 attacks, there were authors who, such as the renowned Jessica Stern, "placed the Triple Frontier among the 
areas with the greatest potential to host jihadist terrorism and posing the greatest risk to US security" (Ferro, 2013).

According to Félix Pablo Friggeri (2017, pp. 188-226), the North American presence in Paraguay is strategic, and it would respond to two fundamental lines of interests: first, to dominate the pivot region between Brazil and Argentina to be well positioned in the event of any hypothetical regional agreement on political matters or management of valuable resources - such as water - that can involve the two great countries of the region and, secondly, Paraguay constitutes a fundamental military point in the region due to the permeability of its borders, the manageability of its corrupt political class, and because both Brazil and Argentina are energy dependent on their joint dams with Paraguay (these latter elements can help the United States destabilizing those countries from Paraguay when the time comes).

For example, on June 16, 2019, there was a "historic blackout" in Argentina, as the former President Mauricio Macri described the massive power outage that affected the city of Buenos Aires and the entire metropolitan area of the capital, as well as practically all of the Argentine provinces, and even areas of Uruguay and some towns in the south of Paraguay itself. The blackout was due to a failure in the energy transportation system from Yacyretá, the dam that Argentina shares with Paraguay, as is the case of Brazil with the bi-national Itaipú dam. This accident shows the potential of destabilization of the region that the control of Paraguayan dams may reach: some hospitals, police stations, communication systems, public services and transportation systems, and most of the residential areas, lacked electricity supply for hours, affecting to a greater or lesser extent almost the entire national territory (with the exception of Tierra del Fuego).

For Friggeri, the intensification of the discourse on the securitization of the Paraguayan State in the years following the parliamentary coup against President Fernando Lugo in 2012, as well as the insistence on strengthening commercial ties with the United States once "Paraguay was freed from its mooring to Latin American organizations" (Friggeri, 2017, p. 212) — says Friggeri with a significant dose of sarcasm, referring to his estrangement from Mercosur and other regional organizations - would be unequivocal symptoms that the United States is intensifying its penetration into the country in order to support its interests and those of the large North American or multinational companies with shared economic interests, a process that several news items in recent years link to the consequences in Paraguayan foreign policy of the parliamentary coup against President Fernando Lugo in 2012 (Resumen Latinoamericano, 2018).

An example of this US penetration was the creation in 2014 (just two years after the coup), by the United States Southern Command in the department of San Pedro, of an installation — with a military presence-, conveniently denominated Operations Center of Emergencies (COE), which was justified based on the argument of protection against natural disasters (Acosta, 2014). Furthermore, at the beginning of 2015 the Secretary of the United States Navy — Ray Mabus - and the US Ambassador to Paraguay Leslie Ann Basset — met with the Paraguayan Defense Minister - Bernardino Estigarribia — to consolidate relationships of trust with the Government of Horacio Cartes, under an alleged commitment to peace, security, stability and strengthening of supposed "democratic values," without forgetting the recurrent discourse of "development" aid, which in Paraguay remained unchanged during the Cartes Government (Telesur, 2018).

But we cannot say that this situation is a novelty, since the United States has been taking positions in Paraguay for decades; in fact, a geostrategic policy analysis of 2011 (Nueva Tribuna) already pointed out the need to understand that the North American intervention in the Guaraní Aquifer is planned in the long term, from a strategic conception, instead of the intuitive or short-term perception by which the most common political and media analysis are usually ruled. Likewise, in this context, the phenomenon of assistance as a domination strategy is also very much present in these processes (Coronel, et al., 2012).

However, not only the North American State has been moving for a long time, but also groups of international capital are interested, where appropriate, in the valuable resources of the country and the region, as is the case of the water contained in the Guaraní Aquifer, appearing in recent years successive news items on supposed interests of big companies like Coca-Cola or Nestlé to privatize the subterranean water resources of the region. Since Michel Temer's usurpation of power in Brazil after Dilma Rousseff's dismissal - the recent succession of political dismissals in the Latin American Southern Cone is striking- 
the liberalizing and deregulating determination shown by his Government to facilitate interests of the great foreign capitals has been much more ostensible; this has been intensified, if possible, with the coming to power of Jair Bolsonaro (with whom Paraguay will probably have to renegotiate the important Itaipú Treaty - the revision of the articles of Annex C of the bi-national agreement is scheduled for 2023- a fundamental and strategic Treaty for the future economic and social development of Paraguay). The Annex $\mathrm{C}$ of the Itaipú Treaty establishes the terms and conditions of the financial bases of the bi-national entity Itaipú, which manages the dam, for the renegotiation of which a commission has recently been formed that will advise the Paraguayan Government (EFE, 2019).

Paraguayan researcher Cecilia Vuyk and her working group are currently one of the few technical teams concerned with setting up a critical debate in Paraguay around this upcoming renegotiation, which in their opinion places the country facing a double challenge: "the negotiation with the Brazilian government, on the one hand, and on the other, the main one, which will be the challenge that we will have within Paraguay, against the positions of surrender of sovereignty that have marked Itaipú's agenda since the very signing of the Treaty onwards" (Vuyk, 2019).

The water conflict with Brazil is, in fact, intertwined with a process of similar importance, such as the issue of Brazilian participation in the development of Paraguayan agribusiness, because although "Paraguay has reinforced its insertion in the global agribusiness chain as supplier of agricultural raw materials," this dynamic has occurred to a large extent "from the regional substructure led by Brazil" in this matter, "which can be verified in the growing expansion of Brazilian investments in Paraguay, specifically, in the meat agribusiness, and in the acquisition of land" (Costa, 2015, p. 138).

It is no coincidence that someone in the position of Peter Brabeck-Letmathe - who was CEO of the Swiss food company Nestlé S.A. since 1997 and President of the group between 2005 and 2008 - is today one of the champions of the cause of the protection of the water (Nestlé España, 2013); and it is not about the idea of equitable redistribution of this and other resources at a global level being uncomfortable per se, what sounds weird to any critical analyst is that the former president of a large business group — with which he has not broken ties of interest - is the person who chairs the organization called the Water Resources Group 2030, or who directs the "Water Initiative" at the World Economic Forum. These are links that, at the very least, invite suspicion, even more so if we take into account that in 2013 there was information indicating that Peter Brabeck-Letmathe had affirmed that water should be privatized, statements that he later qualified by saying that it is necessary to guarantee a minimum per person for drinking and personal hygiene, and that it would be the amount of surplus resource that should be marketed according to business criteria (Abadía Digital, 2013). It should not be forgotten that Nestlé was at that time the world leader in the sale of bottled water - a business that represented close to $8 \%$ of its total revenues in 2011 - nor that this multinational currently has open conflicts of this nature with activists and other organizations in various areas of the planet, including the United States. Nestlé's proceedings generate controversy in Florida because of the multinational's attempts to extract fresh water in contrast with the criticism from civil organizations and environmental activists, who question whether both the environmental impact and damage, as well as the public interest are taken into account (Luscombe, 2019).

To further elaborate on Nestlé's interest in having a presence in Paraguay, it should be noted that the company — a world leader in the production and sale of food and beverages - has recently turned Asunción into one of the nerve centers of its management for Latin America with the creation of a service center (La Nación, 2019) that will provide from Paraguay internal assistance to twenty-one countries in the region, whose inauguration was attended in person by the President of the Government of Paraguay, Mario Abdo Benítez, among other important Paraguayan political representatives.

For its part, the US beverage company Coca-Cola (The Coca-Cola Company), which operates in more countries than the UN, also has important interests in Paraguayan soil. As the company defines itself, CocaCola is a global company that operates at the local level, something that in the opinion of Canese, Ortega and Portillo (2018), allows local franchises — who know better the culture and the political-economic context of the country - profitably managing local or regional particularities, including lobbying to influence local and national politics in their favor, bypassing the legal restrictions that exist in countries like Paraguay for foreigners to participate and influence national political development. In reaction to 
successive information, the multinational soft drink company itself issued a press release in February 2018 in which it stated that "the Coca-Cola Company is not negotiating with any government of any country the exploitation of the Guaraní Aquifer" (Coca-Cola journey, 2018). These statements were due to information that pointed since 2017 to an alleged interest of the company in the privatization of the Guaraní Aquifer in Brazil, in light of the new deregulation policy brought by Temer, which according to information from the beginning of 2018 would be suggesting that private companies can exploit the waters, "with concessions of contracts for more than a hundred years" (Medium, 2018). As in the case of Nestlé, Paraguay is not the only country where the Coca-Cola corporation generates tensions with civil organizations and social activists due to its efforts to exploit water" (Medium, 2018). In 2015, the corporation was accused of overexploitation of an aquifer in El Salvador by a company subcontracted by Coca-Cola, threatening access to water for more than 30,000 people in the Salvadoran municipality of Nejapa (Hernández, 2015).

The Nestlé and Coca-Cola cases arose in 2017, and caused denials from both companies months later, as well as a change of discourse by their main representatives; however, these statements do not weaken the suspicion that the intentions of these and other multinationals are to take advantage of the resources of this international aquifer for their own benefit. Nevertheless, the business need for these corporations to operate in Paraguay and dispose of their resources — as a peripheral country of a capitalist system characterized by the international division of labor and the relocation of resource extraction to regions with a lower development index - also encourages them to comply with the strategic requirement to improve their media image in the country, which has been translated into some social and environmental action projects (Nestlé Paraguay, n.d.; Coca-Cola Journey, n.d.).

It is not intended in this text to demonize these multinationals, but it is necessary to point out that their ample capacity to pressure and urge the competent public and political authorities of a State such as Paraguay should force their managers in the country to take extreme precautions in their negotiations with national institutions and representatives, in order not to exceed the limits of the agreement, the concert of interests and convincing attitude, and avoid reaching the coercion, influence peddling or corruption; furthermore, despite the magnificent prospects for the exploitation of resources in the country, it should not be forgotten that, far above the economic benefits of these companies, they must always place their responsibility towards the local population, which demands sustainable social and environmental development.

It is a fact that international pressures on the water contained in the Guaraní Aquifer - and in particular in Paraguay as one of the main access points - are strong and may be even more so in the future. As previously stated, in terms of groundwater resources of the country, the main current stakeholders are the United States as well as Western multinational companies linked to food production; however, the role that the People's Republic of China could play in this story should not be underestimated. China has two problems with regard to water: firstly, its huge population and its enormous industrial production - the strong economic growth of recent decades "is pushing the country towards the hydrological crisis" (Nueva Tribuna, 2011) - , which require huge amounts of this resource annually, and secondly, the contamination of some of its main sources, such as the great rivers of the region (ABC, 2012), despite the recent multimillion dollar decontamination plan. According to an expert in matters of conflicts over water, "there is no doubt that China is going to be an important player in future water disputes in Asia" (Rodríguez, 2019), and although so far it has chosen to carry out internal transfers without affecting too much the courses of the rivers of its neighboring countries, China is going through a process of "discussion on the management model of its water resources" (Rodríguez, 2019), which could lead it to opt for other systems that would affect its regional relations. However, there is a viable alternative for a country with China's GDP that would avoid some friction —at least with regard to drinking water consumption - such as buying water abroad from countries with a surplus of this resource, as is the case of Paraguay.

In this context, it should be noted that the limited bilateral relations between Paraguay and the People's Republic of China - motivated by Paraguay's official recognition of Taiwan for decades - could be an obstacle to future agreements between both countries. China offers wide commercial opportunities in the context of the recent expansion of the Asian giant into Latin American markets, and for a State of the size and GDP of Paraguay they could be particularly decisive; in the opinion of the specialist in international 
relations Gustavo Rojas, "Paraguay must find a way to take advantage of emerging opportunities while minimizing their potential risks" (Rojas de Cerqueira, 2017, p. 18), for which this Paraguayan-Brazilian analyst proposes a rapprochement with China through adhesion to other international organizations in which it is a part (such as the BRICS bank). In addition, Rojas also considers that "understanding and approaching China pragmatically will also be of growing importance for the future of bi-national hydroelectric plants" (Rojas de Cerqueira, 2017, p. 18), thereby increasing the potential value that Paraguay's water resources — aside from its aquifer reserves - could have in a scenario of rapprochement with China.

Whatever happens in the future - be it the intensification of agreements with the United States, be it a decisive rapprochement with China - in a Paraguay with neoliberal governments in power (Federico Franco, 2012-2013; Horacio Cartes, 2013-2018; and Mario Abdo Benítez, since 2018), it is not easy to imagine that the regulatory laws which define water as a public good and a human right, and describe its ownership as statewide and inalienable, will be duly enforced, even more so if in the recent regional context, other rulers such as the former President of Argentina Mauricio Macri or Jair Bolsonaro in Brazil have continued to bet on the destruction of the public, and of the State's control mechanisms over private activity. The scenario is not at all rosy in this regard; we will remain attentive to the performance of the recently constituted Ministry of the Environment and Sustainable Development in Paraguay, to its regulatory role, and to its control over the sanctions for those who violate the rules of water use and exploitation, as well as the actions of the governments of the region in their relationship with the interests of the United States and the large multinationals in the Guaraní Aquifer.

\section{CONCLUSION}

It is very likely that some wars in the second half of the 21 st century will be caused by differences which arise in the competition for access to water. In this sense, Paraguay - a country so far very unknown, in general, abroad - has rarely aroused international interest, but over time it could become the central focus of a large-scale conflict of international relations due to its importance in the system and the hydrological cycle of the Guaraní Aquifer (one of the largest reserves of fresh water on the planet, capable of supplying the current world population until the beginning of the 23rd century).

The struggle is currently taking place between those who believe that water should be considered a marketable resource and those who, on the contrary, argue that it is a social good tightly linked to the right to life - a "human right" according to the UN-, and therefore they defend that it must be a resource of public property and control. The management of water by the public institutions of the State would guarantee, on paper, a sufficient and adequate supply for the life and economic development of the population of the country or the region; thus, its conversion into an element that favors the enrichment of large multinational private interest groups would be avoided, whose particular benefits would be achieved at the expense of the economic growth of the countries where these reserves are located, and based decisively on the water deprivation suffered by many people all over the planet.

The fact that in the capitalist system "nature" is understood as a "resource" and not as part of the biosocial structure itself, means that water is assigned value as an exploitable and marketable good in this socioeconomic system. This phenomenon - which is part of a broader process related to the advance of neoliberalism in all fields of the production of goods and services in global society - is highly worrisome. Understanding nature as a resource has generated the dangerous idea that the deterioration of the environment and the consequent worsening of the quality of life of the populations of the area do not constitute a real problem until the moment in which what is threatened is the production resulting from the exploitation and extractivism of these natural resources; only then do the alarms go off, when the degree of threat puts the profits of the large private corporations of the capitalist system at risk, while the markets seem to experience little stress when the threat looms over the population (Canese, Ortega \& Portillo, 2018, pp. 25-26).

Paraguay will henceforth be a fundamental player in the dispute for the control and management of the Guaraní Aquifer; although it could be good news in economic terms, it also places this small State in an 
uncomfortable position, as it will become involved in very strong international pressures. The thirty years that have elapsed since the beginning of democracy in the country have placed Paraguay in an acceptable situation in terms of current legal regulations and institutional structure, in a good starting position to protect water resources and guarantee their public ownership and management; however, international pressures - both from countries like the United States and from other transnational forces-, as well as internal private interests, will be strong in the coming decades, and the appropriate performance of the public institutions in charge of water management will depend on the honesty and capacities of their leadership and managerial positions. In this regard, the academics in politics and international relations, on the one hand, and the technical professionals in the regulation and management of natural resources, on the other, will have a lot to say in a scenario in which the interests at stake - economic, political, and social—are huge.

Ultimately, this concerns one of the fundamental debates that international relations will face throughout this century: the global nature debate about the property and the right to use and exploit the natural resources distributed all around the planet; resources that, like oil in the 20th century or water in the present century, have become a permanent focus of international attention due to their high strategic value.

\section{ACKNOWLEDGEMENT}

This article is the translation of a previous work by the same author, originally published in Spanish: Tamayo Belda, E. (2019). “AAntiamericanismo futuro? El interés de Estados Unidos por el Acuífero Guaraní en Paraguay”. In M.A. López Zapico, A. Rodríguez Campesino, \& G. Vitón (Eds.), Nuevas miradas sobre el antiimperialismo y/o el antiamericanismo desde la historia, la literatura y el arte (pp. 89111). Madrid, Spain: Instituto de Estudios Internacionales y Europeos Francisco de Vitoria de la Universidad Carlos III de Madrid.

\section{REFERENCES}

Abadía Digital. (2013, April 22). El presidente de Nestlé cree que el agua no es un derecho, que debería tener un valor de mercado y ser privatizada. Retrieved from https://www.abadiadigital.com/presidente-de-nestle-el-agua-no-es-un-derecho-deberia-tener-unvalor-de-mercado-y-ser-privatizada/

ABC. (2012, January 26). Se dispara la compra de agua potable en China por la contaminación de sus rios. Retrieved from https://www.abc.es/natural/vivirenverde/abci-contaminacion-agua-china201201260000 noticia.html

Ackmouch, A. (2012). Water Governance in Latin America and the Caribbean: A Multi-Level Approach. Paris, France: OECD Publishing.

Acosta, O. (2014, February 22). Inauguran Centro de Operaciones de Emergencias (COE) en San Pedro. Retrieved from http://www.abc.com.py/nacionales/inauguran-centro-de-operaciones-deemergencias-coe-en-san-pedro- 1217730

Apipé, G. (2018). Paraguay importa el 6,2\% de agroquímicos vendidos en el mundo. In Con la soja al cuello 2018 (pp. 32-35). Asuncion, Paraguay: BASE-IS.

Apuuli, K.P. (2011). Recursos naturales transfronterizos en la región del Cuerno de África: El papel de la Estrategia de Paz y Seguridad de la IGAD. Relaciones Internacionales, 18, 67-87.

Arrojo, P. (2009). El reto ético de la crisis global del agua. Relaciones Internacionales, 12, 33-53.

Barlow, M., \& Clarke, T. (2004). Oro Azul. Las multinacionales y el robo organizado de agua en el mundo. Barcelona, Spain: Paidós.

Barreto, M. (2016). Los usos geopolíticos del Paraguay. Revista Integración y Cooperación Internacional, 23, 5-13.

Canese, M., Ortega, G., \& Portillo, A. (2018). ¿De quién es el agua? Asuncion, Paraguay: BASE-IS.

Ceceña, A.E., \& Motto, C.E. (2005). Paraguay: Eje de la dominación del Cono Sur. Buenos Aires, Argentina: Observatorio Latinoamericano de Geopolítica. 
CEPRID. (2013, December 29). Las bases militares de Estados Unidos son puntas de lanza para dominar América Latina y el Caribe. Retrieved from https://www.nodo50.org/ceprid/spip.php?article1800

Coca-Cola Journey. (2018, February 23). Sistema Acuifero Guaraní. Retrieved from https://www.cocacoladeparaguay.com.py/sala-de-prensa/comunicados-de-prensa/sistema-acuifero-guarani

Coca-Cola Journey. (n.d.). Compromiso con el agua. Retrieved from https://www.cocacoladeparaguay.com.py/medio-ambiente/Compromiso-con-el-agua

Coca-Cola Journey. (n.d.). Comunidad. Retrieved from https://www.cocacoladeparaguay.com.py/comunidad

Conca, K. (2006). Governing Water. Contentious Transnational Politics and Global Institution Building. Cambridge, United Kingdom: The MIT Press.

Constantini, F. (2000). Régimen legal y administrativo de las aguas en el Paraguay. Asuncion, Paraguay: Ediciones Hajimeni Enterprises.

Coronel, C., Doughman, R., Duré, E., Irala, A., \& Palau, M. (2012). USAID en Paraguay. La asistencia como estrategia de dominación. Asuncion, Paraguay: BASE-IS / Rosa-Luxemburg Stiftung.

Costa Garay, S.M. (2015). La participación brasileña en el desarrollo del agronegocio en el Paraguay: Un análisis crítico. Novapolis, 9, 127-149.

Díaz Alpuente, F. (2009). Gobernar globalmente las relaciones internacionales del agua. Relaciones Internacionales, 12, 211-218.

Echart Muñoz, E., \& Villarreal Villamar, M.C. (2018). Resistencias y alternativas al desarrollo en América Latina y Caribe; luchas sociales contra el extractivismo. Relaciones Internacionales, 39, 141-163.

EFE. (2019, September 3). Comisión de 27 expertos asesora a Paraguay en el acuerdo de Itaipú con Brasil. Retrieved from https://www.eldiario.es/economia/Comision-expertos-Paraguay-ItaipuBrasil 0 938257000.html

Embid, A., \& Martín, L. (2015). Serie Recursos Naturales e Infraestructura 173. La experiencia legislativa del decenio 2005-2015 en materia de aguas en América Latina. Santiago, Chile: CEPAL.

FAO. (2016). Final evaluation of the Groundwater Governance: A Global Framework for Action. Rome, Italy: FAO.

Ferro Rodríguez, J. (2013, October 19). La Triple Frontera, el Acuifero Guaraní y los intereses de Estados Unidos en la región: Evolución y ¿cambio de escenario? Retrieved from http://www.seguridadinternacional.es/?q=es/content/la-triple-frontera-el-acu\%C3\%ADferoguaran\%C3\%AD-y-los-intereses-de-estados-unidos-en-la-regi\%C3\%B3n

Fretez Bobadilla, A. (2017). Los acuerdos megarregionales y la nueva ofensiva del capital. Asuncion, Paraguay: BASE-IS / Fundación Rosa Luxemburgo.

Friggeri, F.P. (2017). Paraguay después del golpe; el precio de ponerse colorado. Foro Internacional, 227, 188-226.

Gobierno de la Nación Argentina. Ley 5641/2004.

Hernández, M. (2015, June 15). El uso de un acuífero para hacer Coca-Cola amenaza el agua de 30.000 personas en El Salvador. Retrieved from https://www.eldiario.es/desalambre/Agua-El_SalvadorCoca_Cola-Medio_Ambiente_0_397560950.html

Jägerskog, A. (2013). Transboundary water management: Why is it important and why it needs to be developed. In Free Flow: Reaching Water Security through Cooperation (pp. 49-52). Paris, France: UNESCO.

Jalife-Rahme, A. (2015, June 10). ¿Adquirieron los Bush parte del Acuífero Guaraní, el más grande del mundo de agua dulce? Retrieved from https://www.alfredojalife.com/2015/06/10/adquirieron-losbush-parte-del-acuifero-guarani-el-mas-grande-del-mundo-de-agua-dulce/

La Nación. (2019, April 2). Nestlé inauguró centro en Asunción que dará servicios a 21 países de América Latina. Retrieved from https://www.lanacion.com.py/negocios/2019/04/02/nestleinauguro-centro-en-asuncion-que-dara-servicios-a-21-paises-de-america-latina/ 
Larsimont, R., \& Grosso, V. (2014). Aproximación a los nuevos conceptos híbridos para abordar las problemáticas hídricas. Cardinalis, 2, 27-48.

Linton, J., \& Budds, J. (2014). The hydrosocial cycle: Defining and mobilizing a relational-dialectical approach to water. Geoforum, 57, 170-180.

Luscombre, R. (2019, August 27). Nestlé quiere extraer 4,1 millones de litros al día de un manantial 'en recuperación' para vender agua embotellada. Retrieved from https://www.eldiario.es/theguardian/Corren-especies-Florida-embotelladaNestle 0 935806518.html

Martín, L., \& Justo, J.B. (2015). Serie Recursos Naturales e Infraestructura 171. Análisis, prevención y resolución de conflictos por el agua en América Latina y Caribe. Santiago, Chile: CEPAL.

Martínez, M. (2004). SED: Invasión gota a gota, audiovisual documentary, 73 minutes. Argentina: Instituto Nacional de Cine y Artes Audiovisuales (INCAA). Retrieved from https://www.youtube.com/watch?v=AY7EXp3YakQ

Medium. (2018, February 16). Coca-Cola y Nestle se unen para privatizar la mayor reserva de agua de américa del sur. Retrieved from https://medium.com/@Comundia/coca-cola-y-nestle-se-unenpara-privatizar-la-mayor-reserva-de-agua-de-am\%C3\%A9rica-del-sur-5cb77aec981f

Nestlé España. (2013, April 18). Aclaración de Peter Brabeck-Letmathe, expresidente de Nestlé, acerca del agua como derecho humano. Retrieved from https://empresa.nestle.es/es/sobre-nestle/teinteresa-saber/agua-como-derecho-humano

Nestlé Paraguay. (n.d.). Mejorando nuestro desempeño ambiental: nuestro enfoque en el agua. Retrieved from https://www.nestle.com.py/nestle-en-sociedad/csv/nuestras-iniciativas-globaes/mejorandonuestro-desempeo-ambiental-nuestro-enfoque-en-el-agua

Nestlé Paraguay. (n.d.). Nestlé en sociedad: Un futuro saludable. Retrieved from https://www.nestle.com.py/nestle-en-sociedad

Nueva Tribuna. (2011, February 2). A la conquista del acuifero Guaraní. Retrieved from https://www.nuevatribuna.es/articulo/medio-ambiente/a-la-conquista-del-acuferoguaran/20110202054335040039.html

Nueva Tribuna. (2011, January 10). China, agua, agua, agua. Retrieved from https://www.nuevatribuna.es/articulo/medio-ambiente/china-agua-aguaagua/20110110043609040049.html

Ortega, G., \& Portillo, A. (2015). El Agua: ¿bien común o mercancía? Asuncion, Paraguay: BASE-IS / diakonia.

Palau, M. (2006). El lado militar de la ofensiva neoliberal en Paraguay. OSAL, 20, 339-350.

PNUD Paraguay. (2006). Usos y Gobernabilidad del Agua en el Paraguay. Asuncion, Paraguay: PNUD Paraguay / Imprenta AGR.

República del Paraguay. Órgano Legislativo. Constitución Nacional de 1992.

República del Paraguay. Órgano Legislativo. Ley 1561/2000.

República del Paraguay. Órgano Legislativo. Ley 3239/2007.

República del Paraguay. Órgano Legislativo. Ley 6123/2018.

República del Paraguay. Secretaría del Ambiente. Resolución 2155/2005.

República del Paraguay. Secretaría del Ambiente. Resolución 50/2006.

Resumen Latinoamericano. (2015, March 16). Estados Unidos apuesta por Paraguay como lugar clave para su imperio. Retrieved from http://www.resumenlatinoamericano.org/2015/03/16/estadosunidos-apuesta-por-paraguay-como-lugar-clave-para-su-imperio/

Resumen Latinoamericano. (2018, August 19). La sigilosa acción norteamericana en Paraguay y el nuevo mapa militar instalado por Washington en Latinoamérica. Retrieved from http://www.resumenlatinoamericano.org/2018/08/19/la-sigilosa-accion-norteamericana-enparaguay-y-el-nuevo-mapa-militar-instalado-por-washington-en-latinoamerica/

Ribeiro, Ch.R., Bermúdez, O.B., \& Leal, A.C. (2015). A gestão compartilhada de águas transfronteiriças, Brasil e Colômbia. Mercator, 14, 99-118. 
Rodríguez, M. (2019, February 4). China y las futuras guerras del agua. Retrieved from https://empresaexterior.com/art/69228/china-y-las-futuras-guerras-del-agua

Rogers, P. (2002). Water Governance in Latin America and the Caribbean. Fortaleza, Brazil: InterAmerican Development Bank.

Rojas de Cerqueira César, G. (2017). Globalización y desglobalización: ¿Dónde se ubica el Paraguay? Análisis de Coyuntura Mensual: Economía y Sociedad, 49, 16-19.

Telesur. (2018, May 14). ¿Cuál es el interés de EE.UU. en Paraguay? Retrieved from https://www.telesurtv.net/news/cual-interes-estados-unidos-paraguay-20180511-0051.html

United Nations General Assembly. Resolution 64/292. (2010, July 28).

Vuyk, C. (2019, February 26). Paraguay: La revisión del Tratado de Itaipú ya empezó. Retrieved from https://www.marcha.org.ar/paraguay-la-revision-del-tratado-de-itaipu-ya-empezo/ 